\title{
Hippocampal somatostatin receptors and modulation of adenylyl cyclase activity in histamine-treated rats
}

\author{
Lilian Puebla, Eulalia Rodríguez-Martín, Eduardo Arilla * \\ Unidad de Neuroendocrinología Molecular, Departamento de Bioquímica y Biología Molecular, Facultad de Medicina, Unicersidad de Alcalá. Alcalá de \\ Henares, E-28871, Madrid, Spain
}

Accepted 19 July 1995

\begin{abstract}
In the present study, the effects of an intracerebroventricular (i.c.v.) dose of histamine $(0.1,1.0 \mathrm{or} 10.0 \mu \mathrm{g})$ on the hippocampal somatostatin (SS) receptor/effector system in Wistar rats were investigated. In view of the rapid onset of histamine action, the effects of histamine on the somatostatinergic system were studied $2 \mathrm{~h}$ after its administration. Hippocampal SS-like immunoreactivity (SSLI) levels were not modified by any of the histamine doses studied. SS-mediated inhibition of basal and forskolin (FK)-stimulated adenylyl cyclase (AC) activity was markedly increased in hippocampal membranes from rats treated with $10 \mu \mathrm{g}$ of histamine $(23 \% \pm 1 \%$ vs. $17 \% \pm 1 \%$ and $37 \% \pm 2 \%$ vs. $23 \% \pm 1 \%$, respectively). In contrast, neither the basal nor the FK-stimulated enzyme activities were affected by histamine administration. The functional activity of the hippocampal guanine-nucleotide binding inhibitory protein $\left(G_{i}\right.$ protein), as assessed by the capacity of the stable GTP analogue $5^{\prime}$-guanylylimidodiphosphate (Gpp[NH]p) to inhibit FK-stimulated AC activity, was not modified by histamine administration. These data suggest that the increased response of the enzyme to SS was not related to an increased functional activity of $G_{i}$ proteins. In fact, the increased $A C$ response to $S S$ in hippocampal membranes from histamine (10 $\mu \mathrm{g}$ )-treated rats was associated with quantitative changes in the SS receptors. Equilibrium binding data obtained with [ ${ }^{125} \mathrm{IrTyr}{ }^{11}-\mathrm{SS}$ indicate an increase in the number of specific SS receptors $(541 \pm 24 \mathrm{vs} .365 \pm 16 \mathrm{fmol} / \mathrm{mg}$ protein, $P<0.001)$ together with a decrease in their apparent affinity $(0.57 \pm 0.04$ vs. $0.41 \pm 0.03 \mathrm{nM}, P<0.05)$ in rat hippocampal membranes from histamine (10 $\mu \mathrm{g})$-treated rats as compared to control animals. With the aim of determining if these changes were related to histamine binding to its specific receptor sites, the histaminergic $\mathrm{H}_{1}$ and $\mathrm{H}_{2}$ receptor antagonists mepyramine and cimetidine, respectively, were administered $1 \mathrm{~h}$ before histamine injection. The pretreatment with mepyramine or cimetidine induced an increase in the number and affinity constant of the SS receptors whereas the simultaneous pretreatment with both histamine antagonists prevented the histamine-induced changes in SS binding to its receptors. Since the hippocampal SS receptor/effector system is modulated by histamine, it is tempting to speculate that in the hippocampus, SS could be involved as a mediator of the histamine effects on behaviors such as learning and memory.
\end{abstract}

Keywords: Histamine; Somatostatin receptor; Adenylyl cyclase; G-protein; Hippocampus

\section{Introduction}

Somatostatin (SS) is a neuropeptide widely distributed in the brain [11]. In the hippocampus, immunohistochemical studies have revealed many SS-containing interneurons and a profuse network of intrinsic and extrinsic SS-containing fibers that appear to project to pyramidal and granule neurons $[3,18]$. Specific SS receptors are present in the hippocampus [39], suggesting that SS may be a neurotransmitter or neuromodulator in this brain area. Biochemical analysis demonstrated that SS receptors are coupled to

\footnotetext{
- Corresponding author
}

GTP-binding proteins (G-proteins) [22]. The G-proteins then couple the SS receptors with multiple effector proteins to either inhibit them, as occurs with adenylyl cyclase (AC) [44] and voltage-dependent $\mathrm{Ca}^{2+}$ channels [52], or to activate them, as occurs with different $\mathrm{K}^{+}$channels [51]. Several findings suggest an important role for SS in cognitive processes such as learning and memory by modulating neuronal activity in the hippocampus $[2,16]$. Recently, it has been shown that SMS 201-995, a specific peptidase-resistant SS analog, has anticonvulsant activity on EEG seizures induced by glutamate analogs in the hippocampus [50], thus suggesting an inhibitory role of hippocampal SS on seizures.

There are data supporting the hypothesis that the so- 
matostatinergic and histaminergic systems are interrelated and that reciprocal regulation occurs. Centrally administered SS produces a dose-related decrease in histamine levels in the rat hippocampus [7]. Ample evidence exists for histaminergic projections to the hippocampus [33,53], a brain area rich in SS content and receptors [21,40]. These and other subcortical afferents could play a decisive role in the expression of long-term potentiation. Furthermore, several studies suggest that the histamine $\mathrm{H}_{1}$ and $\mathrm{H}_{2}$ receptors may mediate together the actions of histamine in the hippocampus [46]. SS and histamine participate in a similar manner in the regulation of a number of behaviors, including those subserving memory and learning $[2,16,19,46,49]$ and motor activity $[11,46]$. It has been suggested that SS [24] and histamine [43] may act as endogenous anticonvulsants in the hippocampus. In view of all the above, the aim of this study was to elucidate the role of histamine in modulating the SS receptor/effector system in the rat hippocampus. Since it appears that SS modulation of neuronal function involves the inhibition of AC activity by the occupation of receptor sites negatively coupled, via G-proteins, to this enzyme [32], we have assessed the integrity of SS receptor function by assaying both the levels of receptor recognition sites and the ability of $\mathrm{SS}$ to inhibit $\mathrm{AC}$ activity. In addition, we assessed the functional activity of the guanine nucleotide-binding inhibitory protein $\left(\mathrm{G}_{\mathrm{i}}\right)$ and determined the effect of histamine on SS-like immunoreactivity (SSLI) content in the hippocampus. The effects of pretreatment with the histamine $H_{1}$ and $H_{2}$ receptor antagonists mepyramine and cimetidine, respectively, on the above-cited parameters were also evaluated.

\section{Materials and methods}

\subsection{Chemicals}

Synthetic Tyr"-SS and SS-14 were purchased from Universal Biologicals Ltd (Cambridge. U.K.): carrier-free $\mathrm{Na}^{125}$ I (IMS 30, $100 \mathrm{mCi} / \mathrm{ml}$ ) and rabbit antibody were purchased from the Radiochemical Centre (Amersham, UK); histamine hydrochloride, mepyramine maleate, cimetidine, bacitracin, bovine serum albumin (BSA), forskolin (FK), phenylmethylsulfonyl fluoride (PMSF), 3-isobutyl1-methylxanthine (IBMX), GTP and Gpp[NH]p were supplied by Sigma Química (Madrid, Spain). The rabbit antibody used in the radioimmunoassay technique was purchased from the Radiochemical Centre (Amersham, UK). This antiserum was raised in rabbits against SS-14 conjugated to BSA and is specific for SS, but since SS-14 constitutes the C-terminal portions of both $\mathrm{SS}-25$ and SS-28, the antiserum does not distinguish between these three forms. Cross-reactivity with other peptides was less than $0.5 \%$. Cross-reaction with several SS analogues demonstrated that neither the N-terminal glycine nor the
C-terminal cysteine residue is required for antibody binding, suggesting that the antigen site is directed towards the central part of the molecule containing the tryptophan residue. The binding of SS-14 to this antibody does not depend on an intact disulfide bond in the molecule as breaking of the disulfide bond by reaction with $0.1 \%$ mercaptoethanol (boiling water bath, $5 \mathrm{~min}$ ) did not change the immunoreactivity of the peptide.

\subsection{Experimental animals}

The animals used in this study were Wistar rats $(n=60)$ weighing between 200 and $250 \mathrm{~g}$. Rats were maintained on a 12 h light/dark cycle $(07.00-19.00)$ and allowed free access to food. Histamine was dissolved in $0.9 \% \mathrm{NaCl}$ and administered intracerebroventricularly (i.c.v.) in a volume of $10 \mu \mathrm{l}$ according to the method described by Noble et al. [27] at a dose of $0.1,1.0$ or $10.0 \mu \mathrm{g}$ of free base, as previously described [41]. Mepyramine $(30 \mathrm{mg} / \mathrm{kg})$ [28] was dissolved in saline and cimetidine (20 $\mu \mathrm{g} / \mathrm{rat})$ [26] was first dissolved in dimethyl sulfoxide and then diluted with saline to the concentration required. Mepyramine and/or cimetidine were administered via an intraperitoneal (i.p.) and i.c.v. injection, respectively, $1 \mathrm{~h}$ before histamine administration. In all experiments, control animals received equivalent volumes of the corresponding vehicle. Rats were killed by decapitation $2 \mathrm{~h}$ after the last drug injection. The brain was rapidly removed and the hippocampus was dissected over ice according to the method of Glowinski and Iversen [14].

\subsection{Tissue extraction and $\mathrm{SS}$ radioimmunoassay}

For SSLI measurements, the hippocampus was rapidly homogenized in $1 \mathrm{ml} 2 \mathrm{M}$ acetic acid using a Brinkman polytron (setting $5,30 \mathrm{~s}$ ). The extracts were boiled for 5 min in a water bath, chilled in ice, and aliquots $(100 \mu \mathrm{l})$ were removed for protein determination [34]. The homogenates were subsequently centrifuged at $15000 \times g$ for $15 \mathrm{~min}$ at $4^{\circ} \mathrm{C}$ and the supernatant was neutralized with $2 \mathrm{M} \mathrm{NaOH}$. The extracts were then stored at $-70^{\circ} \mathrm{C}$ until assay. The SSLI content was determined in tissue extracts by a modified radioimmunoassay method [34], with a sensitivity limit of $10 \mathrm{pg} / \mathrm{ml}$. Incubation tubes prepared in duplicate contained $100 \mu \mathrm{l}$ samples of unknown or standard solutions of $0-500 \mathrm{pg}$ cyclic SS tetradecapeptide diluted in phosphate buffer $(0.05 \mathrm{M}, \mathrm{pH} 7.2$ containing $0.3 \%$ BSA, 0.01 M EDTA), $200 \mu$ l of appropriately diluted anti-SS serum, $100 \mu \mathrm{l}$ of freshly prepared [ $\left.{ }^{125} \mathrm{I}\right] \mathrm{Tyr}^{11}$-SS diluted in buffer to give $6000 \mathrm{cpm} /$ assay tube (equivalent to $5-10 \mathrm{pg}$ ), and enough buffer to give a final volume of $0.8 \mathrm{ml}$. All reagents, as well as the assay tubes, were kept chilled in ice before their incubation for $48 \mathrm{~h}$ at $4^{\circ} \mathrm{C}$. Separation of bound and free hormone was accomplished by the addition of $1 \mathrm{ml}$ dextran-coated charcoal (dextran T-70: 0.2\% w/v, Pharmacia, Uppsala, Swe- 
den; charcoal Norit A: $2 \% \mathrm{w} / \mathrm{v}$, Serva Feinbiochemica, Heidelberg, Germany). Serial dilution curves for the hippocampus were parallel to the standard curve. The intraand inter-assay variation coefficients were 6.2 and $8.6 \%$, respectively.

\subsection{Binding assay}

Tyr ${ }^{11}$-SS was radioiodinated by chloramine-T iodination according to the method of Greenwood [15]. The tracer was purified in a Sephadex G-25 fine column $(1 \times$ $100 \mathrm{~cm}$ ) equilibrated with $0.1 \mathrm{M}$ acetic acid containing BSA $0.1 \%(w / v)$. The specific activity of the purified labelled peptide was about $600 \mathrm{Ci} / \mathrm{mmol}$.

Hippocampal membranes were prepared as previously described by Reubi et al. [37]. Protein concentration was assayed by the method of Lowry et al. [23], with BSA as a standard. Specific SS binding was measured according to the modified method of Czernik and Petrack [8]. Briefly, the membranes $(0.15 \mathrm{mg}$ protein $/ \mathrm{ml}$ ) were incubated in $250 \mu \mathrm{l}$ of a medium containing $50 \mathrm{mM}$ Tris- $\mathrm{HCl}$ buffer (pH 7.5), $5 \mathrm{mM} \mathrm{MgCl}, 0.2 \%$ (w/v) BSA and $0.1 \mathrm{mg} / \mathrm{ml}$ bacitracin with $250 \mathrm{pM}\left[{ }^{125} \mathrm{I}\right] \mathrm{Tyr}^{11}$-SS either in the absence or presence of 0.01-10 nM unlabelled SS. After a 60 min incubation at $30^{\circ} \mathrm{C}$, bound and free ligand were separated by centrifugation at $11000 \times g$ for $2 \mathrm{~min}$ and the radioactivity in the resultant pellet was measured. Nonspecific binding was obtained from the amount of radioactivity bound in the presence of $10^{-7} \mathrm{M}$ SS and represented about $20 \%$ of the binding observed in the absence of unlabelled peptide. This nonspecific component was subtracted from the total bound radioactivity in order to obtain the corresponding specific binding.

\subsection{Evaluation of radiolabelled peptide degradation}

The inactivation of $\left[{ }^{125} \mathrm{I}\right] \mathrm{Tyr}^{11}-\mathrm{SS}$ in the incubation medium after exposure to membranes was studied by measuring the ability of preincubated peptide to rebind to fresh membranes [1]. Briefly, [ $\left.{ }^{125} \mathrm{I}\right] \mathrm{Tyr}^{11}-\mathrm{SS}(250 \mathrm{pM})$ was incubated with membranes from rat hippocampus $(0.15 \mathrm{mg}$ protein $/ \mathrm{ml}$ ) for $60 \mathrm{~min}$ at $30^{\circ} \mathrm{C}$. After this preincubation, aliquots of the medium were added to fresh membranes and incubated for an additional $60 \mathrm{~min}$ at $30^{\circ} \mathrm{C}$. The fraction of the added radiolabelled peptide which was specifically bound during the second incubation was measured and expressed as a percentage of the binding that had been obtained in control experiments performed in the absence of membranes during the preincubation period.

\subsection{Adenylyl cyclase assay}

AC activity was measured as previously reported [17] with minor modifications. Briefly, hippocampal membranes $(0.06 \mathrm{mg} / \mathrm{ml})$ were incubated with $1.5 \mathrm{mM}$ ATP, 5 $\mathrm{mM} \mathrm{MgSO}_{4}, 10 \mu \mathrm{M}$ GTP, an ATP-regenerating system
(7.5 $\mathrm{mg} / \mathrm{ml}$ creatine phosphate and $1 \mathrm{mg} / \mathrm{ml}$ creatine kinase), $1 \mathrm{mM}$ IBMX, $0.1 \mathrm{mM}$ PMSF, $1 \mathrm{mg} / \mathrm{ml}$ bacitracin, $1 \mathrm{mM}$ EDTA, and test substances $\left(10^{-4} \mathrm{M}\right.$ SS or $10^{-5} \mathrm{M} \mathrm{FK}$ ) in $0.1 \mathrm{ml}$ of $0.025 \mathrm{M}$ triethanolamine $/ \mathrm{HCl}$

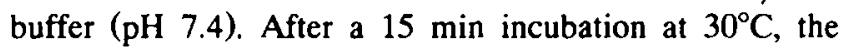
reaction was stopped by heating the mixture for $3 \mathrm{~min}$. After cooling, $0.2 \mathrm{ml}$ of an alumina slurry $(0.75 \mathrm{~g} / \mathrm{ml}$ in triethanolamine/ $\mathrm{HCl}$ buffer, $\mathrm{pH}$ 7.4) was added and the suspension was centrifuged. The supernatant was taken for assay of cyclic AMP (cAMP) by the method of Gilman [13]. The SS concentration used was that necessary to achieve inhibition of rat [44] and human [5,12] brain $\mathrm{AC}$ activity. FK was used at a concentration that could effectively stimulate the catalytic subunit of rat AC [44].

\subsection{Data analysis}

The computer program LIGAND [25] was used to analyze the binding data. The use of this program enabled models of receptors that best fit the given sets of data to be selected. The same program was also used to present the data in the form of Scatchard plots and to compute values for receptor affinity $\left(K_{\mathrm{d}}\right)$ and density $\left(B_{\max }\right)$ that best fit the sets of binding data for each rat. Statistical comparisons of all the data were carried out with one way analysis of variance (ANOVA) and the Student Newman-Keuls test. Means among groups were considered significantly different when the $P$ value was less than 0.05 . Each individual experiment was performed in duplicate.

\section{Results}

As shown in Table 1, SS-mediated inhibition of basal and FK-stimulated AC activity was markedly increased in

Table 1

Effect of somatostatin (SS) $\left(10^{-4} \mathrm{M}\right)$ and forskolin (FK) $\left(10^{-5} \mathrm{M}\right)$ on brain adenylyl cyclase activity (pmol cAMP $/ \mathrm{min} / \mathrm{mg}$ protein) in hippocampal membranes from control rats $(n=15)$ and rats treated with 0.1 $\mu \mathrm{g}(n=5), 1.0 \mu \mathrm{g}(n=5)$ or $10.0 \mu \mathrm{g}(n=5)$ of histamine

\begin{tabular}{lrrrr}
\hline & Control & \multicolumn{3}{l}{ Histamine } \\
\cline { 3 - 5 } & & $0.1 \mu \mathrm{g}$ & $1.0 \mu \mathrm{g}$ & $10 \mu \mathrm{g}$ \\
\hline Basal activity & $119 \pm 4$ & $123 \pm 1$ & $118 \pm 10$ & $121 \pm 2$ \\
$+10^{-4}$ M SS & $99 \pm 4$ & $100 \pm 3$ & $97 \pm 4$ & $93 \pm 2$ \\
\% SS inhibition of & $17 \pm 1$ & $19 \pm 2$ & $18 \pm 1$ & $23 \pm 1 \cdots$ \\
basal activity & & & & \\
$+10^{-5}$ M FK & $634 \pm 16$ & $682 \pm 51$ & $606 \pm 11$ & $631 \pm 38$ \\
$\begin{array}{l}\text { Fold FK stimulation } \\
\text { over basal }\end{array}$ & $5.2 \pm 0.3$ & $5.5 \pm 0.3$ & $5.1 \pm 0.2$ & $5.4 \pm 0.3$ \\
$+10^{-5}$ M FK + & $488 \pm 11$ & $487 \pm 26$ & $478 \pm 6$ & $398 \pm 13$ \\
$10^{-4}$ M SS & & & & \\
\% SS inhibition of & $23 \pm 1$ & $28 \pm 3$ & $21 \pm 3$ & $37 \pm 2 \cdots$ \\
FK stimulation & & & &
\end{tabular}

Values represent the mean \pm SEM of five separate experiments, each performed in duplicate. In the control group, the results express the mean value of a pool of the control animals. Statistical comparison versus control: $\cdots P<0.01, \cdots P<0.001$. 
Table ?

Effect of somatostatin (10: $\mathrm{M})$ and forskolin $\left.(10)^{\circ} \mathrm{M}\right)$ an brain adenylate cyclase activity (pmol/cAMP / min $/ \mathrm{mg}$ protein) in hippocampal membranes from control rats $(n:=10)$ and rats pretreated with mepyramine $(30 \mathrm{mg} / \mathrm{kg}$. i.p.) $(n=5)$ or cimetidine $(20 \mu \mathrm{g}$. i.c.v.) $(n=5) 1 \mathrm{~h}$ before histamine (10 $\mu \mathrm{g}$. i.c.s.) injection

\begin{tabular}{|c|c|c|c|}
\hline & Control & $\begin{array}{l}\text { Mepyramine } \\
\text { plus histamine }\end{array}$ & $\begin{array}{l}\text { Cimetidine } \\
\text { plus histamine }\end{array}$ \\
\hline Basal activity & $120+3$ & $125+6$ & $124+7$ \\
\hline$+10^{-1} \mathrm{M} \mathrm{SS}$ & $101 \pm 2$ & $97 \pm 4$ & $95 \pm 3$ \\
\hline $\begin{array}{l}\% \mathrm{SS} \text { inhibition of } \\
\text { basal activity }\end{array}$ & $16+1$ & $22+2 \cdots$ & $23+.3$ \\
\hline$+10^{-5} \mathrm{MFK}$ & $6.36 \pm 32$ & $64(1+26$ & $0.53 \pm 23$ \\
\hline $\begin{array}{l}+10^{-5} \text { M FK }+ \\
10^{-\dagger} \text { M SS }\end{array}$ & $489 \pm 28$ & $422+34$ & $+24 \pm .31$ \\
\hline $\begin{array}{l}\text { \% SS inhibition of } \\
\text { FK stimulation }\end{array}$ & $23+.3$ & $34 \pm 4$ & $.35+5$ \\
\hline
\end{tabular}

Values represent the mean $\pm S E M$ of five separate experiments, each performed in duplicate. In the control group, the results express the mean value of a pool of the control animals. Statistical comparison versus control: ${ }^{*} P<0.05$. $^{\prime} P<0.01$

hippocampal membranes from rats treated with $10.0 \mu \mathrm{g}$ of histamine as compared with control rats. The response of AC to the diterpene forskolin (FK), which is assumed to act directly upon the catalytic subunit of $\mathrm{AC}$. was also examined. The results obtained indicate that the ability of the diterpene to stimulate the enzyme activity was not altered after histamine administration. In addition, no significant differences were observed for the basal and FKstimulated AC activities between control and histaminctreated $(0.1,1.0$ or $10.0 \mu \mathrm{g}$ ) rats (Table 1). Pretreatment with the histamine $\mathrm{H}_{1}$ or $\mathrm{H}_{2}$ receptor antagonists mepyramine and cimetidine, respectively, also induced an increase in SS-mediated inhibition of basal and FK-stimulated $\mathrm{AC}$ activity (Table 2 ).

Hippocampal $G_{i}$ function, as assessed by inhibiting FK $\left(3 \times 10^{-6} \mathrm{M}\right)$-stimulated AC activity with the stable GTP analog Gpp[NH]p, was similar in control and histamine (10) $\mu \mathrm{g}$ )-treated rats (Fig. 1).

Preliminary experiments confirmed that the specific binding of [ $\left.{ }^{125} \mathrm{I}\right] \mathrm{Tyr}^{11}-\mathrm{SS}$ to hippocampal membranes changed linearly with protein concentration and was timedependent in all experimental groups. An apparent equilibrium was observed between 50 and $180 \mathrm{~min}$ at $30^{\circ} \mathrm{C}$ (data not shown). All subsequent binding experiments were therefore conducted at $30^{\circ} \mathrm{C}$ for $60 \mathrm{~min}$. Hippocampal membranes from all experimental groups showed a similar peptide degradation capacity and the values varied by no more than $10 \%$ among the groups.

SS binding to hippocampal membranes was found to be markedly increased after histamine administration at a dose of $10.0 \mu \mathrm{g}$ as compared with controls (Fig. 2). This increase was due to a rise in the maximal number of SS receptors $(48.2 \%)$, as revealed by Scatchard plots of the binding data (Table 3; Fig. 2). In addition, a significant

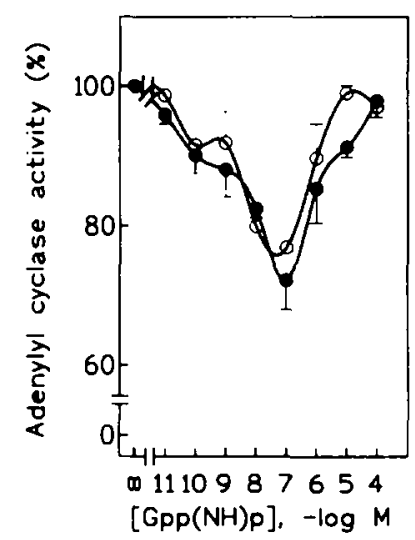

Fig. 1. Dose effect curves for 5 -guanylylimidodiphosphate (Gpp[NH]p)mediated inhibition of adenylyl cyclase (AC) activity in rat hippocampal membrancs from control $(O)(n \therefore 5)$ and histamine $(10.0 \mu \mathrm{g})$-treated (O) $(n=5)$ rats. Curves for the action of Gpp[NH]p on AC activity were carried out in the presence of $3 \times 10^{-6} \mathrm{M}$ forskolin (FK) and the indicated concentrations of GpplNH]p. Data are expressed as a percentage of FK-stimulated AC activity in the absence of $\mathrm{Gpp}[\mathrm{NH}] \mathrm{p}$ (100\%). The results are given as the mean - SEM of five separate determinations, each performed in duplicate. No statistically significant differences were obtained between the control and histamine-treated rats.

decrease in the affinity of these receptors (39\%) was observed (Table 3; Fig. 2). No changes in the number or affinity of the SS receptors were detected at the lower doses of 0.1 or $1.0 \mu \mathrm{g}$ of histamine (Table 3). The addition of $10^{5} \mathrm{M}$ histamine to the incubation medium changed neither the number nor the affinity of the SS receptors in hippocampal membranes from normal rats (data not shown). With the aim of determining if the changes in SS binding were related to histamine binding to its specific receptor sites, the histamine $\mathrm{H}_{1}$ and $\mathrm{H}_{2}$ recep-
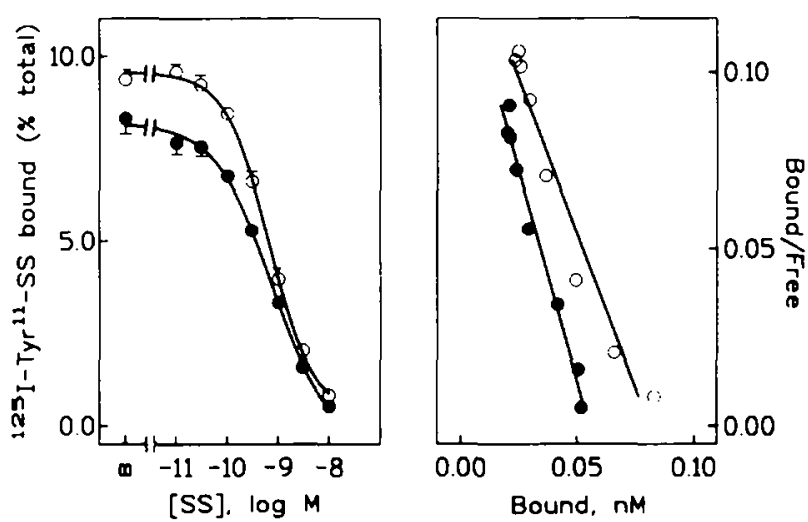

Fig. 2. Effect of histamine (10.0 $\mu$ g, i.c.v.) on somatostatin (SS) binding (1) rat hippocampal membranes. Left pancl: Competitive inhibition of specific [ "25 ITTyr" - SS binding by unlabelled SS to hippocampal membranes. Membranes $(0.15 \mathrm{mg}$ protein $/ \mathrm{ml})$ were incubated for $60 \mathrm{~min}$ at $30^{\circ} \mathrm{C}$ in the presence of $\left.250 \mathrm{pM}\right|^{125} \mathrm{I}_{\mathrm{H}} \mathrm{yr}^{\prime \prime}-\mathrm{SS}$ and increasing concentrations of native peptide. Points correspond to values for the control rats (O) $(n=5)$ and rats treated with $10.0 \mu \mathrm{g}$ of histamine $(O)(n=5)$. Each point represents the mean \pm SEM of five experiments, each performed in duplicate. Right panel: Scatchard analysis of the binding data. 
Table 3

Effect of increasing concentrations of histamine $(0.1 \mu \mathrm{g}, 1.0 \mu \mathrm{g}$ or 10.0 $\mu \mathrm{g})$ and of pretreatment with cimetidine $(20 \mu \mathrm{g} / \mathrm{rat})$ plus mepyramine $(30 \mathrm{mg} / \mathrm{kg})$ administered $1 \mathrm{~h}$ before histamine $(10.0 \mu \mathrm{g})$ on equilibrium parameters for somatostatin (SS) binding to rat hippocampal membranes and on SS-like immunoreactivity (SSLI) concentration in the rat hippocampus

\begin{tabular}{lllll}
\hline Group & \multicolumn{2}{l}{ SS receptors } & SSLI & $n$ \\
\cline { 2 - 4 } & $B_{\max }$ & $K_{\mathrm{d}}$ & & \\
\hline Control & $393 \pm 15$ & $0.32 \pm 0.03$ & $16.14 \pm 1.81$ & 5 \\
Histamine $0.1 \mu \mathrm{g}$ & $428 \pm 16$ & $0.30 \pm 0.03$ & $15.46 \pm 2.09$ & 5 \\
& & & & \\
Control & $408 \pm 14$ & $0.38 \pm 0.03$ & $13.08 \pm 2.19$ & 5 \\
Histamine $1.0 \mu \mathrm{g}$ & $418 \pm 26$ & $0.34 \pm 0.04$ & $14.21 \pm 0.60$ & 5 \\
Control & $365 \pm 16$ & $0.41 \pm 0.03$ & $11.06 \pm 1.27$ & 5 \\
Histamine $10.0 \mu \mathrm{g}$ & $541 \pm 24 \cdots$ & $0.57 \pm 0.04$ & $12.59 \pm 0.86$ & 5 \\
\hline
\end{tabular}

Binding parameters were calculated from Scatchard plots by linear regression. Units for SSLI are $\mathrm{ng}$ of SS per $\mathrm{mg}$ of protein, units for $K_{\mathrm{d}}$ are $\mathrm{nM}$ and units for $B_{\max }$ are fmol of SS bound per $\mathrm{mg}$ of protein. The results are represented as the mean $\pm S E M$ of five separate experiments, each performed in duplicate. Statistical comparison versus control: ${ }^{*} P<0.05$, $\cdots P<0.001$.

tor antagonists mepyramine and cimetidine, respectively, were administered $1 \mathrm{~h}$ before histamine administration. A $29.5 \%$ and $27.2 \%$ increase in the number of SS receptors accompanied by a $69.6 \%$ and $72.7 \%$ decrease in their apparent affinity was observed in rats pretreated with mepyramine or cimetidine, respectively (Table 4). The pretreatment with mepyramine and cimetidine administered simultaneously prevented the histamine-induced changes in SS binding to its receptors (Table 4).

The i.c.v. administration of histamine at a dose of 0.1 , 1.0 or $10.0 \mu \mathrm{g}$ did not significantly affect SSLI content in the hippocampus as compared with the control groups (Table 3).

Table 4

Effect of pretreatment with mepyramine ( $30 \mathrm{mg} / \mathrm{kg}$, i.p.), cimetidine (20 $\mu \mathrm{g}$, i.c.v.) or mepyramine plus cimetidine administered $1 \mathrm{~h}$ before histamine (10 $\mu$ g, i.c.v.) injection on equilibrium parameters for somatostatin (SS) binding to rat hippocampal membranes

\begin{tabular}{lllr}
\hline Group & \multicolumn{2}{l}{ SS receptors } & $n$ \\
\cline { 2 - 3 } & $B_{\max }$ & $K_{\mathrm{d}}$ & \\
\hline Control & $389 \pm 13$ & $0.33 \pm 0.04$ & 15 \\
Mepyramine plus histamine & $504 \pm 20^{\circ}$ & $0.56 \pm 0.04$ & 5 \\
Cimetidine plus histamine & $495 \pm 23^{\circ}$ & $0.57 \pm 0.04 \cdot$ & 5 \\
$\begin{array}{l}\text { Mepyramine plus cimetidine } \\
\text { plus histamine }\end{array}$ & $395 \pm 21$ & $0.33 \pm 0.01$ & 5
\end{tabular}

Binding parameters were calculated from Scatchard plots by linear regression. Units for $K_{\mathrm{d}}$ are $\mathrm{nM}$ and units for $B_{\max }$ are fmol of SS bound per $\mathrm{mg}$ of protein. The results are represented as the mean \pm SEM of five separate experiments, each performed in duplicate. In the control group, the results express the mean value of a pool of the controls $(n=15)$, since the $B_{\max }$ and $K_{\mathrm{d}}$ values were not affected by the vehicle. Statistical comparison versus control: ${ }^{*} P<0.05$.

\section{Discussion}

This study demonstrates for the first time that the number of SS receptors and the AC response to SS are increased in the hippocampus of rats treated with $10.0 \mu \mathrm{g}$ of histamine, an effect that is mediated by both $\mathrm{H}_{1}$ and $\mathrm{H}_{2}$ histaminergic receptors. The hippocampus was chosen to examine the modulation of the SS receptor/effector system due to the high concentration of SS and its receptors $[21,40]$ in spite of the moderate density of histaminergic fibers $[33,53]$ present in this brain area. This moderate density of histaminergic fibers may explain the fact that changes in the somatostatinergic system were only observed at the highest dose tested.

The increased capacity of SS to inhibit basal and FKstimulated AC activity in rats treated with $10.0 \mu \mathrm{g}$ of histamine, as compared with the control group, is most likely related to the observed rise in the number of SS receptors. Indeed, the basal and FK-stimulated enzyme activities are not altered by histamine, suggesting that the catalytic subunit of AC is not involved in the increased response to SS. Furthermore, the functional activity of the $\mathrm{G}_{i}$ protein was similar in the control and histamine (10.0 $\mu \mathrm{g})$-treated group, which suggests that there is no abnormality in the coupling of the SS receptor to AC.

A relatively high concentration of SS $\left(10^{-4} \mathrm{M}\right)$ was required to produce inhibition of $\mathrm{AC}$ activity. This same SS concentration was used by Schettini et al. [44], Bergström et al. [5] and Garlind et al. [12] in their studies on SS-mediated inhibition of AC activity in the rat and human brain. This concentration is three log units higher than that necessary to displace $\left[{ }^{125} \mathrm{I}\right] \mathrm{Tyr}^{11}$-SS binding. A possible explanation for this discrepancy may lie in the observation that G-proteins can modulate the affinity of SS receptors and/or the coupling to the effector system (AC among others). In this respect, Enjalbert et al. [9] and Koch and Schonbrunn [20] have demonstrated that the mobilization of the G-protein by GTP reduces the SS receptor affinity for the neuropeptide in cerebral cortical cells and $\mathrm{GH}_{4} \mathrm{C}_{1}$ pituitary cell clones. Indeed, in the presence of GTP necessary to couple the SS receptor to the AC catalytic subunit, the SS receptor may shift from an apparent high-affinity state (observed in binding studies) to an apparent low-affinity state (observed in AC studies).

The SSLI content and the equilibrium parameters of the SS receptors in the hippocampus of control rats were similar to those previously reported by others [36,47]. Scatchard analysis of the stoichiometric data suggests the existence of only one type of SS receptor. This finding agrees with some studies in rat brain membranes in which $\left[{ }^{125} \mathrm{I}\right] \mathrm{Tyr}{ }^{11}$-SS was also used as a tracer $[10,47]$ but differs from other reported data where different SS analogs were used [38,48]. Recently, five different SS receptor subtypes have been cloned [4] and the tissue distribution of the messenger ribonucleic acid for each subtype has been studied in the rat $[6,35]$. The fact that this study with 
$\left[{ }^{125}\right.$ I]Tyr ${ }^{11}$-SS shows only one type of SS receptor might be explained by the hypothesis that this radioligand binds to all types of SS receptors with dissociation constants that are virtually identical and cannot be discriminated by Scatchard analysis.

Overall, the present data are suggestive of a possible role of histamine as a modulator of the SS receptor/effector system in the hippocampus. The molecular mechanism underlying the increase in SS receptors and SS-mediated $\mathrm{AC}$ inhibition in hippocampal membranes of histamine $(10.0 \mu \mathrm{g})$-treated rats is unknown. This effect, however. seems to be due to a direct interaction of histamine with histaminergic receptors which are present in high density in this brain area $[31,42]$ since the changes induced by this biogenic amine were prevented by pretreatment with the histamine $H_{1}$ and $H_{2}$ receptor antagonists administered simultaneously. In addition, blockade of the histamine $\mathrm{H}_{1}$ or $\mathrm{H}_{2}$ receptors by pretreatment with mepyramine or cimetidine, respectively, induced an increase in the number of SS receptors and in SS-mediated inhibition of $A C$ activity, indicating that both postsynaptic histaminergic receptors, $\mathrm{H}_{1}$ and $\mathrm{H}_{2}$, are implicated in the histamine effects on the hippocampal somatostatinergic system observed in this study. The increase in tracer binding was not due to a direct effect of histamine on SS receptors since no change in [ $\left.{ }^{125} \mathrm{I}\right] \mathrm{Tyr}^{11}$-SS binding was detected following incubation of fresh hippocampal membranes with histamine. The dose response concentration of histamine eliciting an increase in the specific binding of SS in the hippocampus is in good agreement with effective doses of histamine which have been shown to produce a physiological effect [41]. Examples of positive control mechanisms of receptor-receptor interactions include insulin activation of the IGF-II receptor [30], thyrotropin-releasing hormone activation of SS binding [45] and relaxin activation of $\left[{ }^{125}\right.$ I $]$ Tyr $^{11}$-insulin binding [29].

The role of SS receptors in the hippocampus, a structure involved in the regulation of behavior, especially cognitive functions [55], still remains to be elucidated. However, there are several lines of evidence suggesting that SS can play a physiological role in the modulation of this limbic structure [54]. Since the hippocampus receives histaminergic innervation $[33,53]$ and SS receptors are modulated by histamine, it is tempting to speculate that in the hippocampus, SS could be involved as a mediator of the effects of histamine on behaviors such as learning and memory. The importance of this observation for basic science and clinical research requires further exploration.

\section{Acknowledgements}

This work was supported by a Grant from the Dirección General de Investigación Científica y Técnica of Spain.

\section{References}

[1] Aguilera, G., Parker, D.S. and Catt, K.J., Characterization of somatostatin receptors in the rat adrenal glomerulosa zone. Endocrinology, 111 (1982) 1376-1384.

[2] Bakhit. C. and Swerdlow, N.R., Behavioral changes following central injection of cysteamine in rats, Brain Res., 365 (1986) 159-163.

[3] Bakst. I., Avendano, C., Morrison, J.H. and Amaral, D.G., An experimental analysis of the origins of somatostatin-like immunoreactivity in the dentate gyrus of the rat, $J$. Neurosci., 6 (1986) $1452-1462$.

44] Bell, G.I. and Reisine, T., Molecular biology of somatostatin receptors. Trends Neurosci., 16 (1993) 34-38.

[5] Bergström, L., Garlind, A., Nilsson, L., Alafuzoff, I., Fowler, C.J. Winblad. B. and Cowburn, R.F. Regional distribution of somatestatin binding and modulation of adenylyl cyclase activity in Alzheimer's disease brain, J. Neurol. Sci., 105 (1991) 225-233.

(6] Bruno. J.F., Xu. Y.. Song, J. and Berclowitz, M.. Tissue distribution of somatostatin receptor subtype ribonucleic acid in the rat. Endocrinology, 133 (1993) 2561-2567.

[7] Cacabelos, R., Nigawa, H., Yamatodani, A., Gomez-Pan. A.. Nishimura, $T$. and Wada, H., Antagonistic effects of growth hormone-releasing factor and somatostatin on brain histamine, $\mathrm{En}$ docrinology, 122 (1988) 1269-1276.

[8] Czernik. A.J. and Petrack, B., Somatostatin receptor binding in rat cerebral cortex. Characterization using a nonreducible somatostatin analog, J. Biol. Chem., 285 (1983) 5525-5530)

[9] Enjalbert, A., Rasolonn-Janahary, R., Moyse, E., Kordon, C. and Epelbaum, J., Guanine nucleotide sensitivity of [ $\left.{ }^{125} \mathrm{I}\right]-$ iodo-N-Tyrsomatostatin binding in rat adenohypophysis and cerebral cortex. Endocrinology, 113 (1983) 822-824.

[10] Epelbaum, J.. Tapia-Arancibia, L., Kordon, C.. and Enjalbert, A.. Characterization, regional distribution and subcellular distribution of ${ }^{125} 1$-Tyr ${ }^{11}$-somatostatin binding sites in rat brain, J. Neurochem. 38 (1982) $1515-1523$

[11] Epelbaum, J., Somatostatin in the central nervous systcm: physiology and pathological modifications, Prog. Neurobiol.. 27 (1986) $6.3-100$

[12] Garlind, A., Fowler. C.J., Alafuzoff, I.. Winblad, B. and Cowburn, R.F.. Neurotransmitter-mediated inhibition of post-mortem human brain adenylyl cyclase, J. Neural Transm., 87 (1992) 11.3-124.

[13] Gilman. A.G., A protein binding assay for adenosine $3^{\prime} 5^{\prime}$-cyclic monophosphate, Proc. Natl. Acad. Sci. USA, 67 (1970) 305-312.

[14] Glowinski, J. and lversen, L.L.. Regional studies of catecholamines in the rat brain. I. The disposition of $\left[{ }^{3} \mathrm{H}\right]$ norepinephrine, $\left[{ }^{3} \mathrm{H}\right] \mathrm{dopamine}$ and $\left[{ }^{3} \mathrm{H}\right] \mathrm{DOPA}$ in various regions of the brain, $J$. Neurochem. 13 (1966) 655-669.

[15] Greenwood, F.C., Hunter, W.M. and Glover, J.S.. The preparation of ${ }^{131}$ I-labeled human growth hormone of high specific radioactivity, Biochem. J., 89 (1963) 114-123.

[16] Haroutunian, V., Martin, R., Camphell, G.A., Tsuboyama, G.K. and Davies. K.L., Cysteamine-induced depletion of central somatostatin-like immunoreactivity: effects on behavior, learning, memory and brain neurochemistry, Brain Res., 403 (1987) 234-242.

[17] Houslay, M.D., Metcalfe, J.C.. Warren, G.B., Hesketh, T.R. and Smith, G.A., The glucagon receptor of rat liver plasma membranes can couple to adenylate cyclase without activating it, Biochim. Biophys. Acra, 436 (1976) 489-494.

[18] Jöels, M.. Madamba, S.G.. Moore, S.D., Morrison, J.H. and Siggins, G.R., Somatostatin immunohistochemistry of hippocampal slices with Lucifer yellow-stained pyramidal neurons responding to somatostatin, Regul. Peptides. 28 (1990) 215-221.

[19] Kamci, C., Okumura, Y. and Tasaka, K., Influence of histamine depletion on learning and memory recollection in rats, Psychopharmacology, 111 (1993) 376-382.

[20] Koch, B.D. and Schonbrunn, A. The somatostatin receptor is di- 
rectly coupled to adenylate cyclase in $\mathrm{GH}_{4} \mathrm{C}_{1}$ pituitary cell membranes, Endocrinology, 114 (1984) 1784-1790.

[21] Köhler, C. and Chan-Palay, V., Somatostatin-like immunoreactive neurons in the hippocampus: an immunocytochemical study in the rat, Neurosci. Lett., 34 (1982) 259-264.

[22] Law, S., Manning, D. and Reisine, T., Identification of the subunits of GTP-binding proteins coupled to somatostatin receptors, J. Biol. Chem., 266 (1991) 17885-17897.

[23] Lowry, O.H., Rosebrough, N.J., Far, A.L. and Randall, R.J., Protein measurement with the Folin phenol reagent, J. Biol. Chem., 193 (1951) 265-275.

[24] Manfridi, A., Forloni, G.L., Vezzani, A., Fodritto, F. and De Simoni, M.G., Functional and histological consequences of quinolinic and kainic acid-induced seizures on hippocampal somatostatin neurons, Neuroscience, 41 (1991) 127-135.

[25] Munson, P.J. and Rodbard, D., LIGAND: a versatile computerized approach for characterization of ligand binding systems, Anal. Biochem., 107 (1980) 220-239.

[26] Netti, C., Guidobono, F., Olgiati, V.R., Sibilia, V. and Pecile, A., Histamine agonist and antagonist drugs: interference with CNS control of GH release in rats, Hormone Res., 14 (1981) 180-191.

[27] Noble, E.P., Wurtman, R.J. and Axelrod, J., A simple and rapid method for injecting $\mathrm{H}^{3}$-norepinephrine into the lateral ventricle of the rat brain, Life Sci., 6 (1967) 281-291.

[28] Nowak, J.Z. and Zandarowska, E., Histamine in the rat brain: effect of treatment with histidine, histamine $\mathrm{H}_{1}$ - and $\mathrm{H}_{2}$-receptor antagonists and tricyclic antidepressant drugs, Pol. J. Pharmacol. Pharm., 32 (1980) 695-702.

[29] Olefsky, J.M., Seekow, M. and Kroc, R.L., Potentiation of insulin binding and insulin action by purified porcine relaxin, Ann. NY Acad. Sci., 380 (1982) 200-215.

[30] Oppenheimer, C.L., Pessin, J.E., Massague, J., Gitomer, W. and Czech, M.P., Insulin action rapidly modulates the apparent affinity of the insulin-like growth factor II receptor, J. Biol. Chem., 258 (1983) 4824-4830.

[31] Palacios, J.M., Wamsley, J.K. and Kuhar, M.J., The distribution of histamine $\mathrm{H}_{1}$-receptors in the rat brain: An autoradiographic study, Neuroscience, 6 (1981) 15-37.

[32] Panula, P., Yang, H.Y. and Costa, E., Histamine-containing neurons in the rat hypothalamus, Proc. Natl. Acad. Sci. USA, 81 (1984) 2572-2576.

[33] Panula, P., Pirvola, V., Auvinen, S. and Airaksinen, M.S., Histamine-immunoreactive nerve fibers in the rat brain, Neuroscience, 28 (1989) 585-610.

[34] Patel, J.C. and Reichlin, S., Somatostatin in hypothalamus, extrahypothalamic brain and peripheral tissues of the rat, Endocrinology, 102 (1978) 523-531.

[35] Perez, J., Rigo, M., Kaupmann, K., Brunns, C., Yasuda, K., Bell, G.I., Lübbert, H. and Hoyer, D., Localization of somatostatin (SRIF) SSTR-1, SSTR-2 and SSTR-3 receptor mRNA in rat brain by in situ hybridization, Naunyn Schmiedeberg's Arch. Pharmacol., 349 (1994) $145-160$.

[36] Pitkänen, A., Sirviö, J., Jolkkonen, J. and Riekkinen, P., Somatostatin-like immunoreactivity and somatostatin receptor binding in rat brain before and after pentylenetetrazol-induced convulsions, $\mathrm{Neu}$ ropeptides, 7 (1986) 63-71.

[37] Reubi, J.C., Perrin, M.H., Rivier, J.E. and Vale, V., High affinity binding sites for the somatostatin-28 analogue in rat brain, Life Sci., 28 (1981) 2191-2198.
[38] Reubi, J.C., Evidence for two somatostatin-14 receptor types in rat brain cortex, Neurosci. Lett., 49 (1984) 259-263.

[39] Reubi, J.C. and Maurer, R., Autoradiographic mapping of somatostatin receptors in the rat central nervous system and pituitary, Neuroscience, 15 (1985) 1183-1193.

[40] Roberts, G.W., Woodhams, P.L., Polak, J.M. and Crow, T.J., Distribution of neuropeptides in the limbic system of the rat: the hippocampus, Neuroscience, 11 (1984) 35-77.

[41] Rodriguez, J., Toledo, A., Brandner, R., Rodriguez, R., Sabria, J. and Blanco, I., Histamine $\mathrm{H}_{2}$-receptor-mediated activation of neonatal rat brain ornithine decarboxylase in vivo, Biochem. Pharmacol., 37 (1988) 551-554.

[42] Ruat, M., Traiffort, E., Arrang, J.M., Leurs, R. and Schwartz, J.C., Cloning and tissue expression of a rat histamine $\mathrm{H}_{2}$-receptor gene, Biochem. Biophys. Res. Commun., 179 (1991) 1470-1478.

[43] Scherkl, R., Hashem, A. and Frey, H.H., Histamine in brain - its role in regulation of seizure susceptibility, Epilepsy Res., 10 (1991) $111-118$.

[44] Schettini, G., Florio, T., Meucci, O., Landolfi, E., Grimaldi, M., Ventra, C. and Marino, A., Somatostatin inhibition of adenylate cyclase activity in different brain areas, Brain Res., 492 (1989) 65-71.

[45] Schonbrunn, A. and Tashjian, A.H. Jr., Modulation of somatostatin receptors by thyrotropin-releasing hormone in a clonal pituitary cell strain, J. Biol. Chem., 255 (1980) 190-198.

[46] Schwartz, J.C., Arrang, J.M., Garbarg, M., Pollard, H. andRuat, M., Histaminergic transmission in the mammalian brain, Physiol. Ret., 71 (1991) 1-51.

[47] Srikant, C.B. and Patel, Y.C., Somatostatin receptors: identification and characterization in rat brain membranes, Proc. Natl. Acad. Sci. USA, 78 (1981) 3930-3934.

[48] Tran, V.T., Beal, M.F. and Martin, J.B., Two types of somatostatin receptors differentiated by cyclic somatostatin analogs, Science, 228 (1985) 492-495.

[49] Vécsei, L., Bollok, I. and Telegdy, G., Comparative studies with cyclic and linear somatostatin on active avoidance behaviour and open-field activity in rats, Acta Physiol. Hung., 61 (1983) 43-49.

[50] Vezzani, A., Serafini, R., Stasi, M.A., Vigano, G., Rizzi, M. and Samanin, R., A peptidase-resistant cyclic octapeptide analogue of somatostatin (SMS 201-995) modulates seizures induced by quinolinic and kainic acid differently in the rat hippocampus, Neuropharmacology, 30 (1991) 345-352.

[51] Wang, H.L., Bogen, C., Reisine, T. and Dichter, M., Somatostatin-14 and somatostatin-28 induce opposite effects on potassium currents in rat neocortical neurons, Proc. Natl. Acad. Sci. USA, 86 (1989) 9616-9620.

[52] Wang, H.L., Reisine, T. and Dichter, M., Somatostatin-14 and somatostatin-28 inhibit calcium currents in rat neocortical neurons, Neuroscience, 342 (1990) 335-342.

[53] Watanabe, T., Taguchi, Y., Shiosaka, S., Tanaka, J., Kubota, H., Terano, Y., Tohyama, M. and Wada, H., Distribution of the histaminergic neuron system in the central nervous system of rats: a fluorescent immunohistochemical analysis with histidine decarboxylase as a marker, Brain Res., 295 (1984) 13-25.

[54] Watson, T.W.J. and Pittman, Q.J., Pharmacological evidence that somatostatin activates the $M$-current in hippocampal pyramidal neurons, Neurosci. Lett., 91 (1988) 172-176.

[55] Zola-Morgan, S. and Squire, L.R., Neuroanatomy of memory, Annu. Rei. Neurosci., 16 (1993) 547-563. 